Петр Матвеевич Мазуркин,

зав. кафедрой природообустройства,

Поволжский государственный технологический университет, проф., д-р техн. наук, академик ЕАЕ, РАЕ и РАЕН, 424036, ул. Комсомольская, 92А, 69, г. Йошкар-Ола, Республика Марий Эл, тел. (8362)686011, (8362)420774, 8-964-860-80-25, E-mail: kaf_po@mail.ru

Анастасия Игоревна Кудряшова, магистрант 2 курса 120700.68 «Землеустройство и кадастры», Александр Николаевич Фадеев, доц., канд. техн. наук, кафедра природообустройства ПГТУ

\title{
Вейвлет-анализ распределений центров кадастровых кварталов города
}

Аннотация На примере городских кадастровых кварталов показано начало вейвлет-анализа по основной части города Йошкар-Ола, приведена методика статистического моделирования асимметричными вейвлет-сигналами с переменными амплитудой и периодом колебаний.

Ключевые слова: город, квартала, центры, координаты, вейвлет-анализ

Abstract The urban cadastral quarters shows the start of the wavelet analysis on the main part of the city of Yoshkar-Ola, the technique of statistical modeling asymmetric wavelet signals with variable amplitude and period of oscillations.

Keywords: city, district centers, coordinates, wavelet analysis

Введение. Устойчивое прогрессивное развитие городов в сторону создания комфортной среды обитания становится основной тенденцией XXI века в мире.

Под устойчивым развитием (анг. - sustainable development) понимается такая модель развития современного общества, в которой удовлетворение потребностей настоящего поколения не ставит под угрозу возможность для будущих поколений удовлетворять в полной мере свои собственные потребности. Концепция устойчивого развития формировалась в ходе постепенного осознания обществом природоохранных, экономических и социальных проблем, оказывающих влияние на состояние природной среды. Это - конструктивная реакция общества на наблюдаемые и активно освещаемые в научных публикациях и средствах массовой информации процессы деградации природы под усиленным антропогенным давлением [16].

Финляндия отличается невероятным прогрессом в создании комфортной городской среды. В основе лежит эффективное сотрудничество архитекторов, строителей, органов власти и местных сообществ. В 2012 г. Международный совет по промышленному дизайну назвал Хельсинки «Столицей мирового дизайна». Хельсинки это обычный северный город со снегами, реагентами и мехуборкой, но здесь удается воплощать концепцию «города в природе». На форуме 23-28 апреля 2015 г. в Хельсинки будет рассмотрен ландшафтный урбанизм и город в природе. Изучается видовой состав и приживаемость растений в городе, использование рельефа, материалы и конструкции. Как сделать городскую среду устойчивой и привлекательной [17].

Для нашей статьи применим девиз «Умный - значит зелёный» [15].

По мнению Мэтью Смита, «умный» город просто неизбежно будет экологически устойчивым. Аналогичной точки зрения придерживается, например, и д-р Бойд Коэн (Boyd Cohen). Ta- 
кой город, доказывает Смит, не расходует попусту энергию на освещение и отопление. Система умных парковок сокращает выбросы выхлопных газов автомобилей. Датчики предупредят коммунальные службы о неполадках в водопроводной или газовой сети, когда те ещё только назревают, уменьшая утечки. Наконец, система управления дорожным движением «умного города» не только создаст «зелёную волну» для кареты «скорой помощи», но и передаст в больницу все данные по пациенту ещё до того, как его доставят, экономя время и спасая жизнь.

Проект «Умный и безопасный г. Казань»- детище Cisco Systems, правительства Татарстана и городских властей Казани. Он должен снизить затраты в сфере ЖКХ на 80\%, затраты на освещение города - на 40\%, уменьшить количество транспортных пробок на четверть. Кроме того, на 50\% возрастёт эффективность пользования общественным транспортом. Проект предусматривает единую городскую сеть Wi-Fi и видеонаблюдения, интеллектуальную транспортную систему, контроль городской среды и экологической обстановки, «умную» парковку, «умный» автобус, «умное» уличное освещение, контекстную рекламу, «умное» ЖКХ [15].

Однако до сих пор не рассматриваются математические закономерности сложившейся городской среды. Многие средовые решения города разрабатываются ныне больше на уровне искусства, интуиции и опыта специалистов. Поэтому цель статьи - показать на примере города Йошкар-Ола, одного из экологических центров Приволжского федерального округа, закономерности волнового распределения городских кварталов в рамках принятого зонирования.

Метод вейлвет-анализа. Гильберт мечтал об инвариантах, - как из кирпичиков будет собираться универсальное уравнение Декарта. Наши универсальные инварианты даны в таблице 1.

\section{Таблица 1. Математические конструкты (исходные инварианты или кирпичики Гильберта) для составления статистической модели}

\begin{tabular}{|c|c|}
\hline $\begin{array}{c}\text { Фрагменты без предыстории } \\
\text { изучаемого явления или процесса }\end{array}$ & $\begin{array}{c}\text { Фрагменты с предысторией } \\
\text { изучаемого явления или процесса }\end{array}$ \\
\hline $\begin{array}{l}y=a x-\text { закон линейного роста или спада } \\
\text { (при отрицательном знаке перед правой } \\
\text { стороной формулы линейного изменения) }\end{array}$ & $\begin{array}{l}y=a \text { - закон не влияния принятой объяс- } \\
\text { няющей переменной на показатель, который } \\
\text { имеет собственную предысторию значений }\end{array}$ \\
\hline $\begin{array}{l}y=a x^{b} \text { - закон показательного роста (закон } \\
\text { показательной гибели } y=a x^{-b} \text { не является } \\
\text { устойчивым, из-за бесконечности значения } \\
\text { показателя при нулевом значении объяс- } \\
\text { няющей переменной) }\end{array}$ & $\begin{array}{l}y=a \exp ( \pm c x) \text { - закон Лапласа в математике } \\
\text { (Ципфа в биологии, Парето в экономике, } \\
\text { Мандельброта в физике) экспоненциального } \\
\text { роста или гибели, на нем Лаплас создал ме- } \\
\text { тодологию операторного исчисления }\end{array}$ \\
\hline $\begin{array}{l}y=a x^{b} \exp (-c x) \text { - биотехнический закон в } \\
\text { упрощенной форме (П.М. Мазуркин), когда } \\
\text { показательный рост постепенно получает } \\
\text { экспоненциальное торможение }\end{array}$ & $\begin{array}{l}\text { кон экспоненциального } \\
\text { олной форме (конструк- } \\
\text { интенсивность, не рав- } \\
\text { Мазуркин) }\end{array}$ \\
\hline
\end{tabular}

Особенности предложенной методологии [6] анализа различных явлений и процессов, имеющих колебательное возмущение, асимметричными вейвлет-сигналами даны в статьях [5, 9 , 
$18,19]$ и учебных пособиях $[3,7,11]$. Практические примеры идентификации волновыми функциями показаны в статьях $[1,2,4,8,10,12-14]$.

Инварианты колебательных возмущений в виде асимметричных вейвлет-сигналов включают в себя конструкты из таблицы 1 как амплитуда (половина) и полупериод.

Устойчивые законы и закономерности на их основе делают выбор уравнения для последующей идентификации на статистических данных (числовых полях) вполне осмысленным, и вероятностное моделирование остается только при случайном поиске программной средой типа CurveExpert значений параметров у искомой модели. Поэтому из теории идентификации первый этап (выбор случайной структуры уравнения) исключается и остается только второй этап случайная идентификация значений параметров модели.

Структура модели идентифицируется обработкой исходных данных так:

- вначале выявить детерминированные нелинейные закономерности;

- затем дополнять эти тренды колебательными возмущениями.

В таблице 2 приведены интервалы коэффициента корреляции как меры адекватности.

Таблица 2. Уровни адекватности статистических моделей

\begin{tabular}{|c|c|c|c|c|}
\hline \multirow[b]{2}{*}{$\begin{array}{c}\text { Интервал } \\
\text { коэффициента } \\
\text { корреляции }\end{array}$} & \multicolumn{4}{|c|}{ Характер тесноты связи между факторами } \\
\hline & $\begin{array}{l}\text { существующая } \\
\text { классификация }\end{array}$ & $\begin{array}{c}\text { шкала для } \\
\text { технических } \\
\text { измерений } \\
\end{array}$ & $\begin{array}{c}\text { шкала для } \\
\text { прецизионных } \\
\text { измерений } \\
\end{array}$ & $\begin{array}{c}\text { шкала для генной } \\
\text { инженерии и рядов це- } \\
\text { лых простых чисел }\end{array}$ \\
\hline 1 & \multirow{6}{*}{ сильная связь } & однозначная & однозначная & однозначная \\
\hline $0.999 \ldots 1.0000$ & & \multirow{4}{*}{ сильнейшая } & \multirow{2}{*}{ почти однозначная } & почти однозначная \\
\hline $0,99 \ldots 1,000$ & & & & чрезвычайно сильная \\
\hline $0,95 \ldots 0,99$ & & & сверхсильная & сверхсильная \\
\hline $0,90 \ldots 0,95$ & & & сильнейшая & сильнейшая \\
\hline $0,7 \ldots 0,9$ & & сильная & сильная & сильная \\
\hline $0,5 \ldots 0,7$ & \multirow{2}{*}{ слаб } & средняя & средняя & средняя \\
\hline $0,3 \ldots 0,5$ & & слабоватая & слабоватая & слабоватая \\
\hline $0,1 \ldots 0,3$ & \multirow{3}{*}{ нет связи } & слабая & Слабая & слабая \\
\hline $0,0 \ldots 0,1$ & & слабейшая & слабейшая & слабейшая \\
\hline 0 & & нет связи & нет связи & нет связи \\
\hline
\end{tabular}

Существующая шкала квантификации тесноты связи между принятыми факторами (нет связи, слабая и сильная связь) является очень грубой.

Критерием (количественной мерой) идентификации становится погрешность измерений при составлении числового поля, т.е. таблицы исходные данных. Математические числовые объекты [18] - наилучшие для идентификации законов-инвариантов.

На втором месте находятся прецизионные измерения в астрономии, физике, технике и технологии, других областях науки. На третье место встают биологические объекты [12], и их поведение имеет четко проявляющийся колебательный характер. Самые высокие погрешности имеют социально-экономические измерения из-за их значительной субъективности. 
Нами предложена для технических экспериментов, в которых погрешность измерений не превышает 5\%, другая шкала (третий столбец таблицы 2). Однако выяснилось, что этой шкалы уровней адекватности также недостаточно.

Для многих природных (биологических) объектов и результатов прецизионных физических измерений пришлось ввести еще два интервала уровня адекватности по четвертому столбцу таблицы 1, что нами было выполнено только при моделировании распределений рядов простых чисел [18]. А для генной инженерии пришлось ввести еще один уровень адекватности [18].

Мы придерживаемся концепции Декарта о необходимости применении алгебраического уравнения общего вида как конечного математического решения неизвестных интегральных уравнений. Для обобщения был предложен новый класс волновых функций $[5,9,18,19]$.

Сигнал - это материальный носитель информации. А информация нами понимается как меpa взаимодействия. Сигнал может генерироваться, но его приём не обязателен. Сигналом может быть любой физический процесс или его часть. Получается, что изменение множества неизвестных сигналов давно известно, например, через ряды гидрометеорологических измерений во многих точках планеты. Однако до сих пор не получены их статистические модели.

Асимметричный вейвлет-сигнал для большинства примеров моделирования имеет вид

$$
y_{i}=A_{i} \cos \left(\pi x / p_{i}-a_{8 i}\right),
$$

$$
A_{i}=a_{1 i} x^{a_{2 i}} \exp \left(-a_{3 i} x^{a_{4 i}}\right), p_{i}=a_{5 i}+a_{6 i} x^{a_{7 i}},
$$

где $y$ - показатель (зависимый фактор), $i$ - номер составляющей (1), $m$ - количество членов в модели (1), $x$ - объясняющая переменная (влияющий фактор), $a_{1} \ldots a_{8}$ - параметры, принимающие числовые значения в ходе структурно-параметрической идентификации (1), $A_{i}$ - амплитуда (половина) вейвлета (ось $y$ ), $p_{i}$ - полупериод волны (ось $x$ ).

Исходные данные. Генеральный план городского округа "Город Йошкар-Ола" - столицы субъекта Российской Федерации - Республики Марий Эл - разработан в 2004 - 2007 гг. (рис. 1). научно-проектным институтом пространственного планирования "ЭНКО" (Санкт-Петербург). Он был выполнен с учетом Градостроительного кодекса РФ (2004 г.), Земельного кодекса РФ (2001 г.), Федерального закона от 6 октября 2003 г. N 131-Ф3 "Об общих принципах организации местного самоуправления в Российской Федерации", других законов и нормативных актов.

Город Йошкар-Ола может поставить задачу претендовать на "экологическую и спортивную столицу" Поволжья, так как для этого есть все основания - красивый, чистый, активно развивающийся город. Через 20-30 лет Йошкар-Ола может стать умной и зеленой средой.

Генеральным планом намечены мероприятия по развитию городской системы озеленения и формированию природного каркаса городского округа "Город Йошкар-Ола" - реконструкция и создание новых элементов городского озеленения - парков, скверов, бульваров, спортивных и рекреационных зон, благоустройство зеленой зоны города. Долина реки Малая Кок- 
шага рассматривается как центральный архитектурно-ландшафтный комплекс Йошкар-Олы, является его главной экологической и архитектурно-планировочной осью.

Сеть городских кварталов основной части поселения приведены ан рисунке 2.

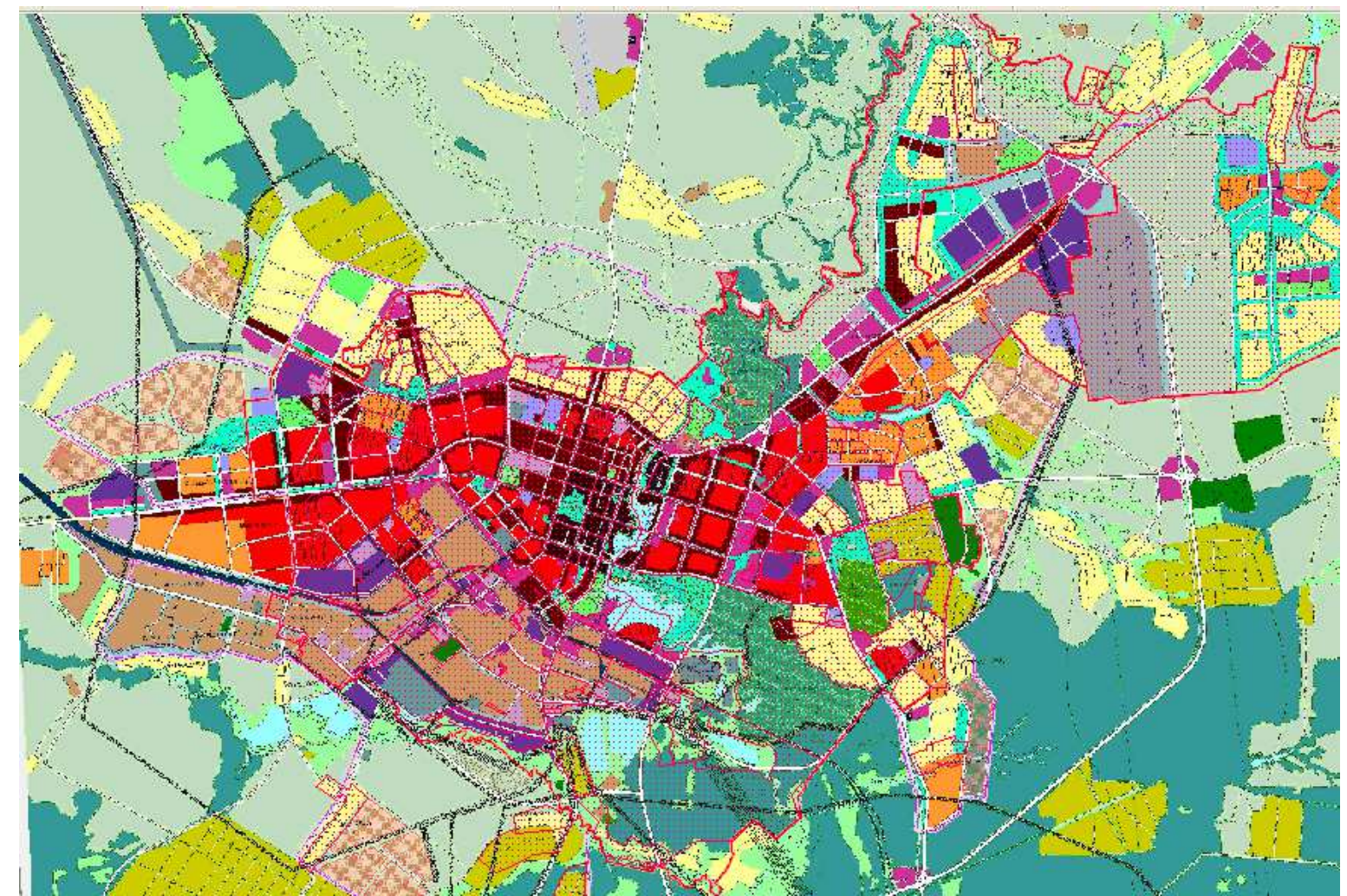

Рисунок 1. Генеральный план города Йошкар-Ола

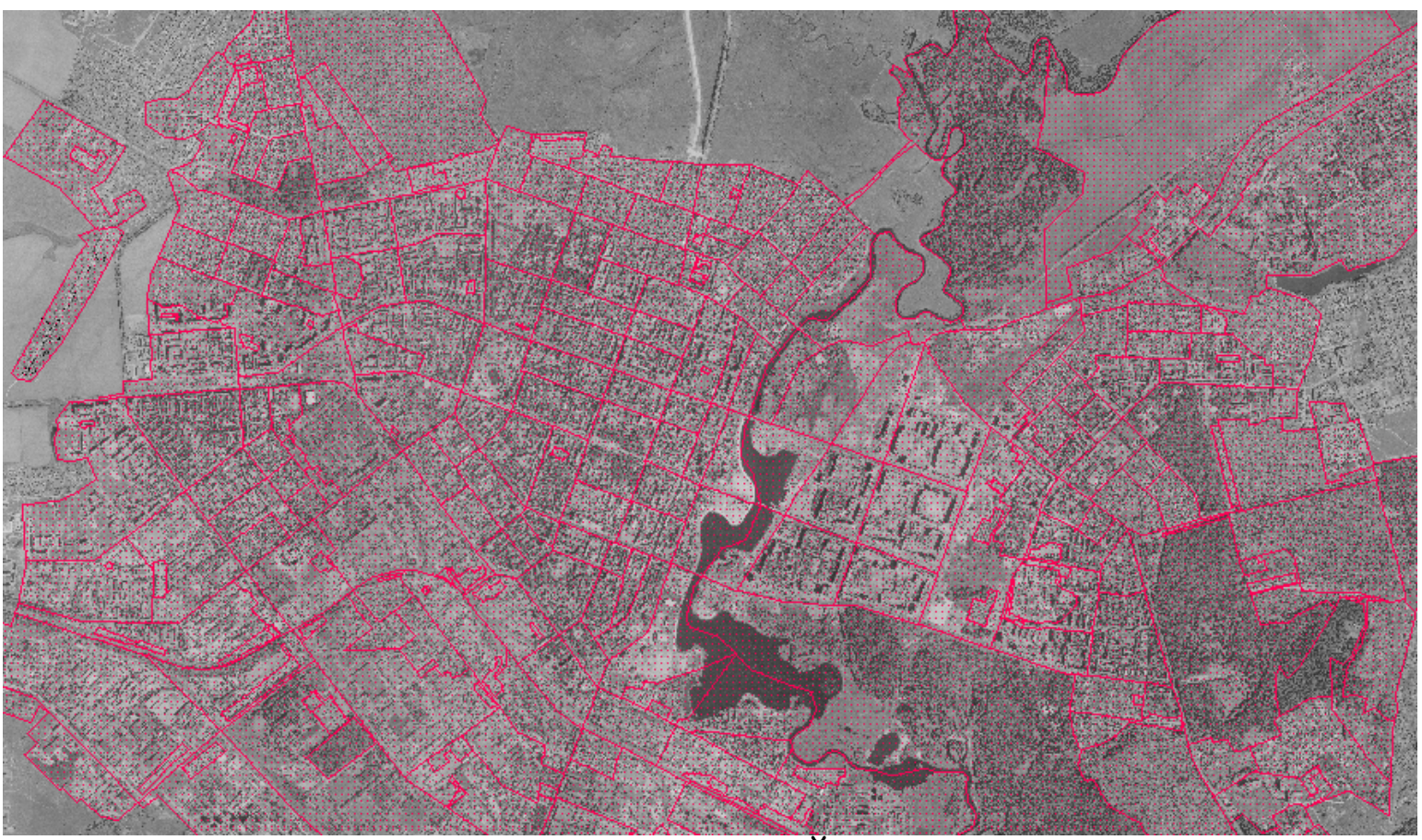

Рисунок 2. Кадастровые городские кварталы Йошкар-Ола в ГИС «Карта-2011»

Из Генерального плана города нами был выделена основная часть в количестве 303 кадастровых кварталов (рис. 2), по которым в ГИС «Карта-2011» были выделены условные координаты, периметр и площадь квартала (табл. 3) в урезанной местной системе координат МСК-12. 
Дополнительно были рассчитаны предлагаемые параметры формы кадастрового квартала. Для оценки возможности статистического моделирования вначале была рассмотрена совокупность из всех 303 кадастровых квартала, затем массив исходных данных из 204 кадастровых квартала, включающая по данным таблицы 4 три городские зоны и 10 подзон (в последующих статьях).

Таблица 3. Данные по 303 городским кварталам основной части города

\begin{tabular}{|c|c|c|c|c|c|c|c|}
\hline \multirow{2}{*}{$\begin{array}{l}\text { № } \\
\Pi / \Pi\end{array}$} & \multirow{2}{*}{$\begin{array}{c}\text { Код } \\
\text { зоны }\end{array}$} & \multicolumn{2}{|c|}{$\begin{array}{c}\text { Координаты } \\
\text { центра квартала }\end{array}$} & \multicolumn{2}{|c|}{$\begin{array}{c}\text { Параметры } \\
\text { квартала }\end{array}$} & \multicolumn{2}{|c|}{$\begin{array}{c}\text { Параметр формы } \\
\text { квартала }\end{array}$} \\
\hline & & $Y(x), M$ & $\mathrm{X}(y), \mathrm{M}$ & $P, \mathrm{M}$ & $S, \mathrm{M}^{2}$ & $S / P, \mathrm{M}$ & $100 S / P^{2}, \%$ \\
\hline 1 & 0 & 2534 & 12419 & 182 & 1683 & 9.26 & 5.0932 \\
\hline 2 & 11 & 4087 & 10090 & 1440 & 113639 & 78.94 & 5.4831 \\
\hline 3 & 0 & 6024 & 10872 & 189 & 1890 & 10.00 & 5.2973 \\
\hline 4 & 11 & 8578 & 10552 & 1184 & 80294 & 67.81 & 5.7272 \\
\hline 5 & 11 & 9335 & 11373 & 1475 & 107570 & 72.95 & 4.9477 \\
\hline 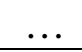 & $\ldots$ & ... & $\cdots$ & $\ldots$ & $\cdot$ & . & $\ldots$ \\
\hline 299 & 0 & 3579 & 7717 & 9601 & 1571508 & 163.69 & 1.7049 \\
\hline 300 & 11 & 2311 & 10773 & 2944 & 303212 & 102.99 & 3.4980 \\
\hline 301 & 33 & 9411 & 8606 & 996 & 55350 & 55.56 & 5.5777 \\
\hline 302 & 11 & 4047 & 11932 & 2355 & 238139 & 101.11 & 4.2933 \\
\hline 303 & 0 & 9950 & 9126 & 9033 & 1361407 & 150.72 & 1.6685 \\
\hline
\end{tabular}

В таблице 3 приведены условные обозначения координат центров кадастровых кварталов:

$x$ - условная координата центра кадастрового квартала по широте Y (абсцисса), м,

y - условная координата центра кадастрового квартала по долготе Х (ордината), м.

Закономерности распределения по городу. На рисунке 3 приведен график закономерности распределения центров у кадастровых кварталов города Йошкар-Ола по формуле

$$
y=9513,698+0,085403 x-A \cos (\pi x / p-6,27154),
$$

$$
\begin{aligned}
& A=2,15270 \cdot 10^{-37} x^{10,57540} \exp \left(-0,00088049 x^{0,95491}\right), \\
& p=891,40285+0,12611 x^{1,00909} .
\end{aligned}
$$

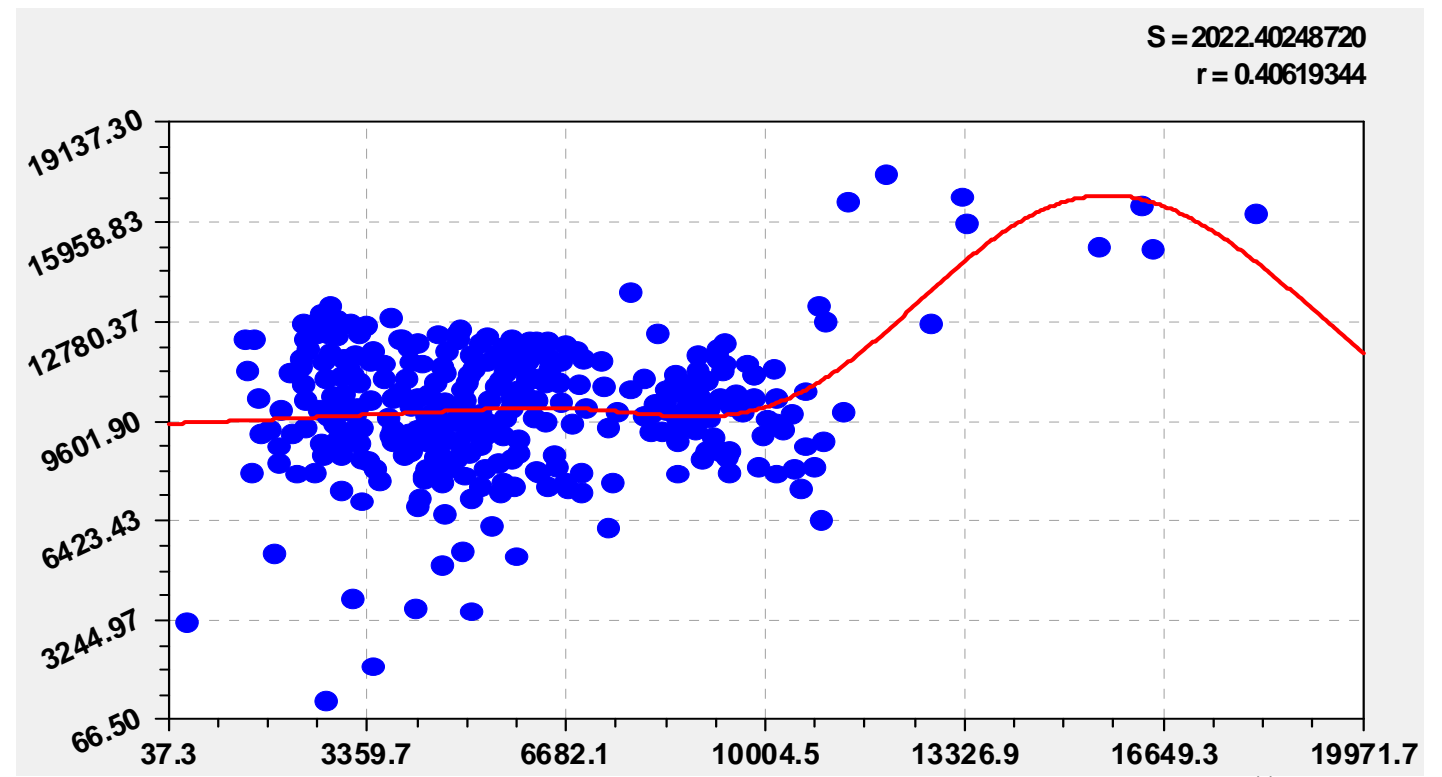

Рисунок 3. График распределения 303 центров у кадастровых кварталов Йошкар-Ола:

$S$ - сумма квадратов отклонений (дисперсия); $r$ - коэффициент корреляции 
Трехчленная модель (1) содержит от запада к востоку основную ось $y_{1}=9513,698$ м, имеющий небольшой наклон $y_{2}=0,085403 x$ к широте. За 40 лет, по мере расширения города на восток, произошло возмущение центров кварталов по вейвлету $y_{3}=-A \cos (\pi x / p-6,27154)$. При условии $x=0$ получаем полупериод колебания $p_{0}=891,40285$ или 891,4 м.

Закономерности по трем зонам. Получена средне адекватная модель вида (1) с коэффициентом корреляции 0,5928, параметры которой приведены в таблице 4 (рис. 4).

Таблица 4. Параметры модели (1) по трем зонам города Йошкар-Ола

\begin{tabular}{|c|c|c|c|c|c|c|c|c|c|}
\hline \multirow{3}{*}{$\begin{array}{c}\text { Ho- } \\
\text { мep } \\
i\end{array}$} & \multicolumn{8}{|c|}{ Асимметричный вейвлет $y_{i}=a_{1 i} x^{a_{2 i}} \exp \left(-a_{3 i} x^{a_{4 i}}\right) \cos \left(\pi x /\left(a_{5 i}+a_{6 i} x^{a_{7 i}}\right)-a_{8 i}\right)$} & \multirow{3}{*}{$\begin{array}{c}\text { Коэфф. } \\
\text { коррел. } \\
r\end{array}$} \\
\hline & \multicolumn{4}{|c|}{ амплитуда (половина) колебания } & \multicolumn{3}{|c|}{ полупериод колебания } & сдвиг & \\
\hline & $a_{1 i}$ & $a_{2 i}$ & $a_{3 i}$ & $a_{4 i}$ & $a_{5 i}$ & $a_{6 i}$ & $a_{7 i}$ & $a_{8 i}$ & \\
\hline 1 & 10028,9 & 0 & 0 & 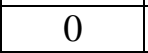 & 0 & ( & 0 & 0 & \multirow{6}{*}{0,5} \\
\hline 2 & 1,2028 & 4,43527 & 0 & 0 & 0 & 0 & 0 & 0 & \\
\hline 3 & $4,53340 \mathrm{e}-74$ & 20,96742 & 014778 & 1,01225 & 151,10 & 043915 & 00471 & 3,89520 & \\
\hline 4 & 891,70399 & 0 & 0 & 0 & 1725 , & 0 & 0 & $-1,54711$ & \\
\hline 5 & $-601,27196$ & 0 & 0 & 0 & 50,30 & 0 & 0 & $-0,37592$ & \\
\hline 6 & $1,40712 \mathrm{e}-43$ & 14,28269 & 0,0032236 & 1 & 195, & 0 & 0 & 2,43999 & \\
\hline 7 & $3,60689 \mathrm{e}-40$ & 13,89056 & 0,0045286 & 0,99664 & 24,93868 & 0 & 0 & 0,46699 & \\
\hline
\end{tabular}

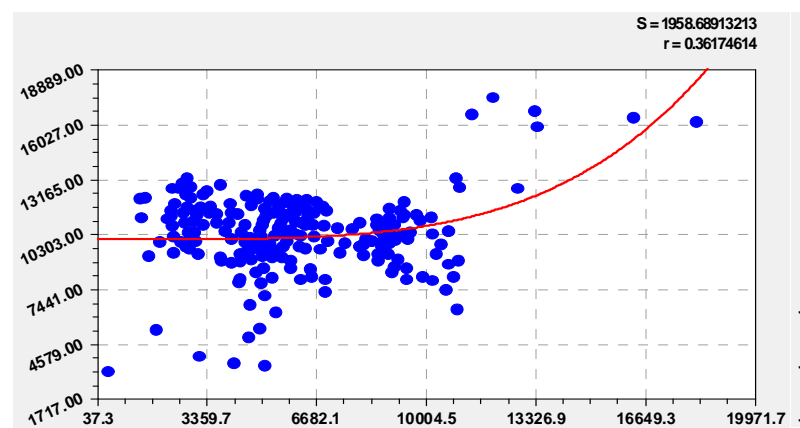

Двухчленный тренд

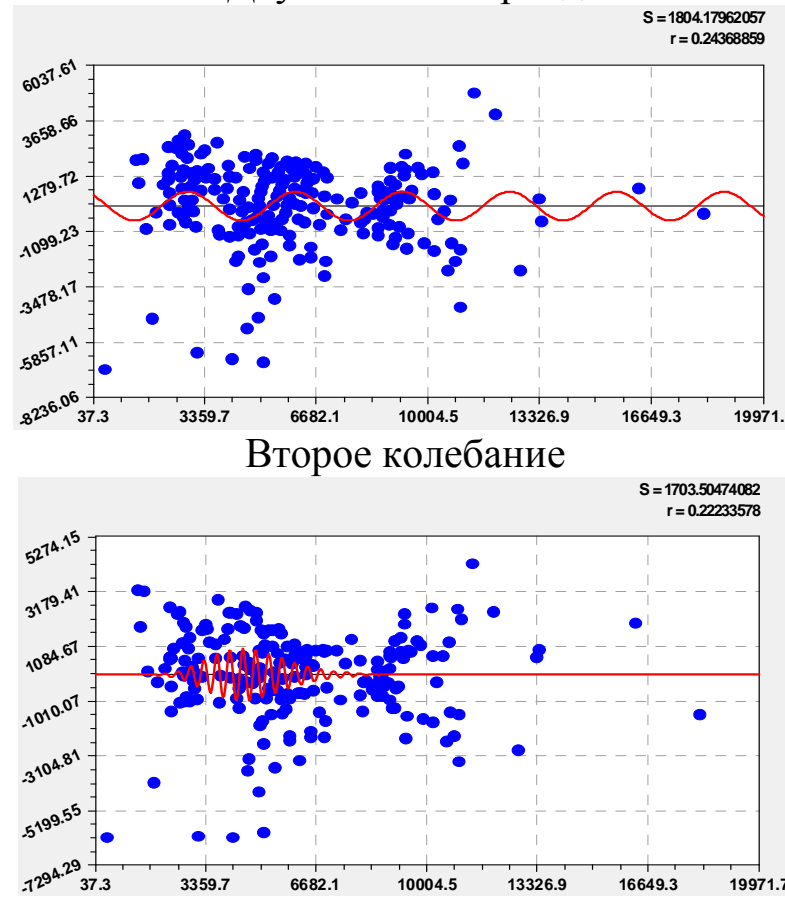

Четвертое колебание

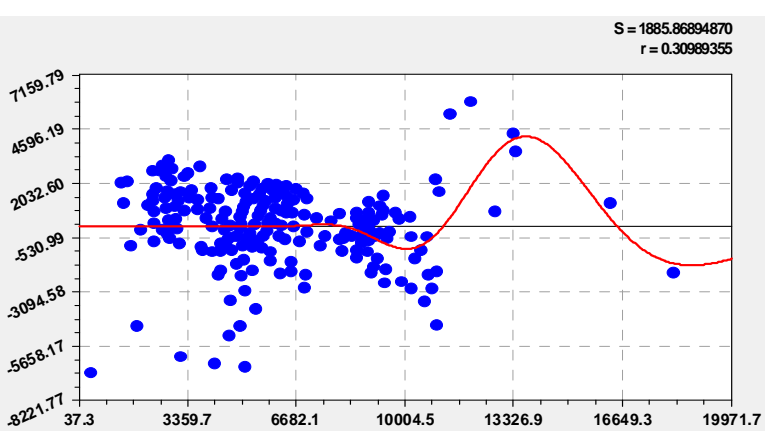

Первое колебание

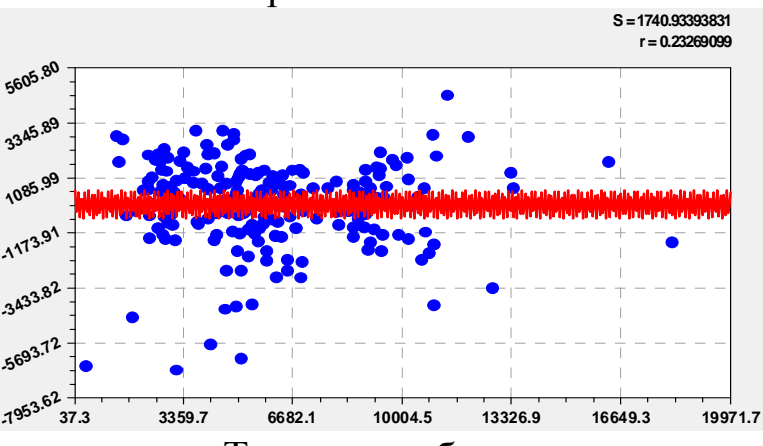

Третье колебание

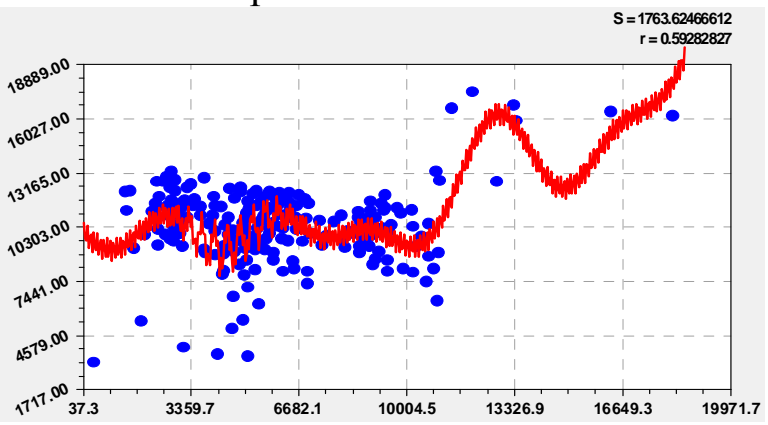

График шестичленной модели (1)

Рисунок 4. Графики общей закономерности по трем зонам города Йошкар-Ола 
По множеству из 303 городских кадастровых кварталов было получено семь членов общей модели (1), из которых по возможностям программной среды CurveExpert-1.40 были совместно рассмотрены шесть составляющих. С учетом дополнительных колебаний адекватность общей статистической модели повысится. С повышением однородности множества кадастровых кварталов по группам по иерархии кадастровых кварталов, адекватность модели (1) также растет.

Заключение. Выявленные по статистическим данным городской среды биотехнические закономерности позволяют лучше понять складывающуюся во времени эволюции города структуру и функции отдельных зон и городских кварталов. Достоинством волновых уравнений является возможность их применения в различных прогнозных расчетах. Они позволяют создать имитационную модель распределения элементов городских кварталов, а на основе оценки этих распределений намечать мероприятия по улучшению растительного покрова каждого квартала.

\section{Список литературы}

1. Кудряшова А.И. Рейтинг земель Тульской области по районам // «Опыт прошлого взгляд в будущее» - 4-я Международная научно-практическая конференция молодых ученых и студентов. Материалы конференции: ТулГУ, Тула, 2014, С. 376-381.

2. Мазуркин П.М. Агроэкологические зоны Тульской области // Матер. конф. «Социальноэконом. и экологич. проблемы горной пром-ти, строительства и энергетики». 8-я Междунар. конф. по проблемам горной промышленности, строительства и энергетики. Том 2. Тула: ТулГУ, 2014. C. $248-256$.

3. Мазуркин П.М. Биокаркас территории: учеб. пос. с грифом УМО РАЕ. Йошкар-Ола: Поволжский ГТУ, 2013. 156 с.

4. Мазуркин П.М. Динамика землепользования субъекта федерации // Землеустройство и кадастры: проблемы и пути их решения. Матер. Междунар. науно-практ. конф. в рамках пленарного засед. Совета УМО вузов по образ. в области землеустройства и кадастров / Под общ. ред. В.В. Вершинина. М.: ГУЗ, 2013. С. 94-99.

5. Мазуркин П.М. Идентификация статистических устойчивых закономерностей // Наука и мир: международный научный журнал. 2013. № 3(3). С.28-33.

6. Мазуркин П.М. Колебательное возмущение эргатической системы // Фундаментальные исследования. № 11 (часть 2). 2013. С. 266-271.

7. Мазуркин П.М. Коррелятивная вариация: учеб. пос. с грифомУМО РАЕ. Йошкар-Ола: Поволжский ГТУ, 2013. 120 с.

8. Мазуркин П.М. Прогноз землепользования в России // Землеустройство и кадастр недвижимости: проблем и пути их решения. Матер. научно-практ форума, посв. 235-летию со дня основания Госуд. ун-та по землеустройству / Под общ. ред. С.Н. Волкова, В.В. Вершинина. М.: ГУЗ, 2014. С. 61-67. 
9. Мазуркин П.М. Решение 23-ой проблемы Гильберта Междисциплинарные исследования в области математического моделирования и информатики. Матер. 3-й научно-прак. internetконф. Ульяновск: SIMJET, 2014. C 269-277.

10. Мазуркин П.М. Тенденции землепользования в России // Модернизация системы управления объектами недвижимости: сб. научн. тр. I междунар. науч.-практ. конф. 22-23 октября 2014 г., Пенза: ПГУАС, 2014. С. 109-113.

11. Мазуркин П.М. Экологический баланс территории: учеб. пос. с грифом УМО РАЕ. Йошкар-Ола: Поволжский ГТУ, 2013. 152 с.

12. Мазуркин П.М., Кудряшова А.И., Волновая динамика онтогенеза листьев загрязненной около автомобильной дороги липы // http://research-journal.org/: Международный научноисследовательский журнал. 2015. URL: http://research-journal.org/?p=10958 (дата обращения 28.01.2015).

13. Мазуркин П.М., Фадеев А.Н. Доля сельхозземель Тульской области // Матер. конф. «Социально-эконом. и экологич. проблемы горной пром-ти, строительства и энергетики». 8-я Междунар. конф. по проблемам горной промышленности, строительства и энергетики. Том 2. Тула: ТулГУ, 2014. С. 234-239.

14. Мазуркин П.М., Фадеев А.Н. Геоинформационные системы земельного кадастра, лесного реестра и особо охраняемых территорий // Современные проблемы науки и образования. № 4. 2009. C.69-75.

15. Панасанко С. Город - новая утопия, или горе от ума? 3 февраля 2015. URL: http:/greencity.su/novaya-utopiya-ili-gore-ot-uma/ (Дата обращения 18.02.2015).

16. Понятие устойчивого развития. URL: http://green-agency.ru/ponyatie-istoriya-i-sferyustojchivogo-razvitiya/ (Дата обращения 28.02.2015).

17. Создание комфортной городской среды XXI века. 23-28 апреля 2015, Финляндия. URL: http://green-agency.ru/best_urban/ (Дата обращения 18.02.2015).

18. Mazurkin P.M. Method of identification $/ / 14^{\text {th }}$ International multidisciplinary scientific geoconferenct \& SGEM2014. GeoConference jn NANO, BIO AND GREEN - TECHNOLOGIES FOR A SUSTAINABLE FUTURE. Conference proceedincs. Volume 1. Section Advances in Biotechnology. 17-26 June 2014. Albena, Bulgaria. P. 427-434.

19. P.M. Mazurkin. Statistical modeling of entire prime numbers / International Journal of Engineering and Technical Research (IJETR) ISSN: 2321-0869, Volume-2, Issue-8, August 2014. P.148158. 